\title{
GTF2B wt Allele
}

National Cancer Institute

\section{Source}

National Cancer Institute. GTF2B wt Allele. NCI Thesaurus. Code C52955.

Human GT F2B wild-type allele is located within 1p22-p21 and is approximately $39 \mathrm{~kb}$ in length. This allele, which encodes transcription initiation factor IIB protein, is involved in transcription through the modulation of the formation of the RNA polymerase II preinitiation complex. 